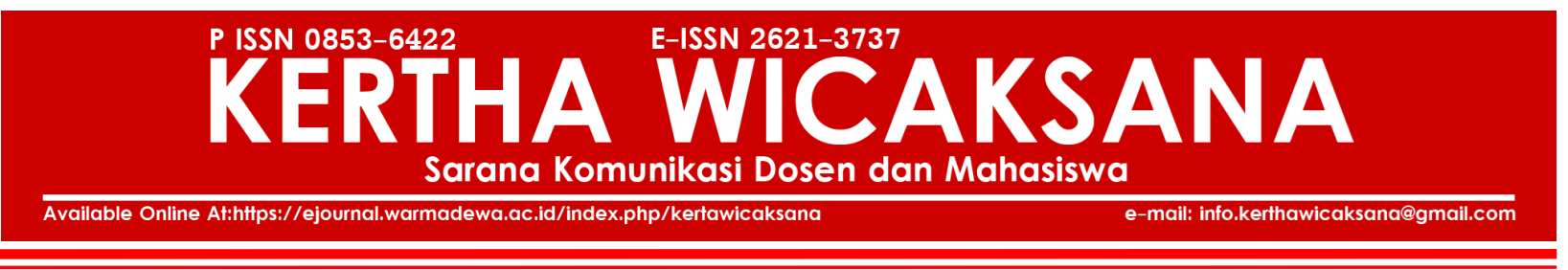

\title{
Penerapan Sanksi Adat dalam Penistaan Tempat Suci di Desa Padang Tegal, Kecamatan Ubud, Kabupaten Gianyar
}

\author{
Diah Gayatri Sudibya, Dessy Lina Oktaviani Suendra*, Kade Richa Mulyawati \\ Universitas Warmadewa, Denpasar-Bali, Indonesia \\ *dessysuendra@gmail.com
}

Published: 30/01/2021

How To Cite:

Sudibya, D, G., Suendra, D, L, O., Mulyawati, K, R. (2021). Penerapan Sanksi Adat dalam Penistaan Tempat Suci di Desa Padang Tegal, Kecamatan Ubud, Kabupaten Gianyar. KERTHA WICA KSANA : Sarana Komunikasi Dosen dan Mahasiswa. 15 (1). Pp 18 - 25. https://doi.org/10.22225/kw.14.2.1863.77-86

\begin{abstract}
Abstrak
Tidak dapat kita pungkiri bahwa Bali merupakan salah satu destinasi wisata yang memiliki popularitas yang tinggi. Para wisatawan tersebut sangat jatuh cinta dengan adat dan budaya yang ada di Bali tetapi tidak sedikit wisatawan yang tidak memahami arti penting tempat suci yang terdapat dalam kawasan daya tarik wisata. Untuk melindungi tempat suci yang banyak tersebar di Bali diperlukan adanya sanksi baik dalam peraturan perundang-undangan maupun berupa awig-awig desa agar dapat menjerat pelaku penistaan terhadap tempat suci di Bali tetapi sayangnya hal tersebut belum diatur secara tegas di dalam peraturan yang ada. Adapun perrmasalahan yang diangkat untuk dianalisa dan dijawab dalam penelitian ini adalah 1.Bagaimanakah Penerapan Sanksi Adat Dalam Penistaan Tempat Suci Menurut Hukum Positif ? 2. Bagaimanakah Penyelesaian Kasus Penistaan Tempat Suci Di Desa Padang Tegal, Kecamatan Ubud, Kabupaten Gianyar ? Metode yang digunakan adalah model penelitian hukum empiris. Produk hukum di Indonesia belum mengatur mengenai penistaan terhadap tempat suci secara nyata, dalam KUHP hanya diatur mengenai penistaan agama dan tidak disinggung mengenai penistaan tempat suci. Dalam kasus penistaan tempat suci di Desa Padang Tegal diselesaikan dengan sanksi adat dan melalui proses mediasi oleh Bendesa adat desa Padang Tegal dengan pelaku. Namun sayangnya sanksi adat ini kurang memberikan efek jera bagi pelaku dan hanya mengembalikan kesucian dari tempat suci itu sendiri.
\end{abstract}

\section{Kata Kunci: Bali; Penistaan Tempat Suci; Sanksi Adat}

\begin{abstract}
Bali is one tourist destination that has high popularity. These tourists really fall in love with the customs and culture that exist in Bali but not a few tourists do not understand the importance of the holy places contained in the tourist attraction area. To protect the holy places that are widely scattered in Bali, it is necessary to have sanctions both in the statutory regulations and in the form of village awig-awig in order to ensnare the perpetrators of defamation of holy places in Bali, but unfortunately this has not been strictly regulated in the existing regulations. The problems raised to be analyzed and answered in this study are 1. How is the application of customary sanctions in defamation of holy places according to positive law? 2. What is the settlement of the case of defamation of holy places in Padang Tegal Village, Ubud District, Gianyar Regency? The method used is an empirical legal research model. Legal products in Indonesia do not regulate defamation of holy places in real terms, the Criminal Code only regulates religious blasphemy and does not mention defamation of holy places. In the case of the defamation of the holy place in Padang Tegal Village, it was resolved with customary sanctions and through a mediation process by the customary Bendesa of Padang Tegal Village with the perpetrators. But unfortunately this customary sanction does not provide a deterrent effect on the perpetrators and only restores the sanctity of the holy place itself.
\end{abstract}

Keywords: Bali; Blasphemy of Holy Places; Adat Sanctions 


\section{PENDAhuluan}

Semakin berkembangnya zaman maka semakin berkembang pula berbagai tindak pidana yang mengganggu keberlangsungan agama di Indonesia, salah satunya adalah tindak pidana penistaan agama. Persoalan mengenai penistaan atau ujaran kebencian terhadap agama semakin mendapat perhatian masyarakat dan aparat penegak hukum, baik nasional maupun internasional (Rustamaji \& Aulia, 2020). Hal ini telah diatur dalam Penetapan Presiden Nomor 1 Tahun 1965 tentang Pencegahan Penyalahgunaan dan/atau Penodaan Agama j.o Undang-Undang Nomor 5 Tahun 1965 tentang Pernyataan Berbagai Penetapan Presiden dan Peraturan Presiden sebagai Undang-Undang Penodaan Agama. Selain kasus penistaan Agama, hal lainnya yang kerap kali terjadi adalah tindak pidana pelecehan atau penistaan tempat suci di Kawasan Daya Tarik Wisata (DTW). Tempat suci atau pura merupakan lembaga terpenting di pulau Bali dan ilustrasi paling jelas dari semangat agama orang Bali (Covarrubias, 2013).

Sebagai symbol dari agama hindu di Bali, Pura memiliki nilai khusus yang sakral dan tidak boleh ternodai. Pura bagi umat Hindu menurut pendapat Anak Agung Oka Netra adalah sebagai sarana untuk memuja Ida Sang Hyang Widhi Wasa beserta seluruh manifestasinya dan juga sebagai tempat memuja roh suci leluhur dengan berbagai macam tingkatannya. Sedangkan secara khusus fungsi tempat suci merupakan sarana untuk meningkatkan kualitas umat manusia, baik sebagai makhluk individu maupun makhluk sosial. Secara individu ini berfungsi untuk mengkomunikasikan Sang Hyang Atma yang ada pada diri manusia denganTuhan Yang Maha Esa Sebagai Sumbernya (Netra, 1997). Sedangkan secara social berfungsi sebagai tempat sarana dan prasarana melakukan kegiatan sosial, misalnya kegiatan bermusyawarah, pendidikan, melaksanakan sumpah janji suci pernikahan, dan lain sebagainya

Namun dengan semakin berkembangnya pariwisata di Bali pada akhirnya mengijinkan pura sebagai kawasan Daya Tarik Wisata, maka tidak menutup kemungkinan untuk terjadinya kasus penistaan tempat suci. Kasus yang paling terbaru terkait penistaan tempat suci terjadi pada
10 Agustus 2019 di Objek Wisata Monkey Forest Ubud yang dilakukan oleh dua WNA asal Republik Ceko. Dua WNA ini adalah Sabina Dolezalova dan Jdenek Slova yang melakukan penistaan tempat suci dengan cara mencuci bokong menggunakan air yang mengucur dari sebuah pelinggih yang disucikan umat Hindu.

Jika kita menilik dari hukum pidana, sesungguhnya tindak pidana pelecehan atau penistaan tempat suci perlu mendapatkan perhatian lebih dalam hal penjatuhan sanksi pidana. Hal ini dikarenakan semakin maraknya kegiatan-kegiatan penistaan tempat suci namun tidak ada sanksi tegas oleh Pemerintah Indonesia untuk menyelesaikannya sehingga para wisatawan baik luar mapun dalam negeri masih saja ada yang melakukan tindak penistaan tempat suci. Tempat suci yang menjadi destinasi tempat wisata kerap kali memberikan akses yang mudah bagi para wisatawan untuk berpergian keluar masuk area pura dan hal ini kerap kali berdampak kepada sering terjadinya kasus penistaan tempat suci di kawasan Daya Tarik Wisata di Bali. Berdasarkan latar belakang tersebut maka penulis akan melakukan penelitian dengan judul Penerapan Sanksi Adat Dalam Penistaa Tempat Suci Di Desa Padang Tegal, Kecamatan Ubud, Kabupaten Gianyar.

Adapun penulis hendak mengkaji permasalah sebagai berikut :

Bagaimanakah Penerapan Sanksi Adat Dalam Penistaan Tempat Suci Menurut Hukum Positif ?

Bagaimanakah Penyelesaian Kasus Penistaan Tempat Suci Di Desa Padang Tegal, Kecamatan Ubud, Kabupaten Gianyar?

\section{METODE}

Penelitian yang dipergunakan dalam penyusunan artikel ini adalah tipe penelitian empiris. Penelitian empiris menurut Soerjono Soekanto disebut juga penelitian hukum sosiologis, yang terdiri dari penelitian terhadap indentifikasi hukum (tidak tertulis) dan penelitian terhadap efektifitas hukum (Soekanto, 2007). Dalam penelitian ini dipergunakan pendekatan perundang-undangan (statue approach), pendekatan konsep (conceptual approach) dan pendekatan analitis (analyicialapproach). Data yang digunakan dalam penyusunan skripsi ini terdiri dari 2 (dua) jenis yaitu: Data Primer dan Data Sekunder. Teknik Pengumpulan data yang digunakan dalam penelitian ini adalah:Teknik wawancara, Teknik Studi Dokumen dan Teknik 
Observasi/Pengamatan.

\section{III.HASIL PENELITIAN DAN PEMBAHASAN}

\section{Penerapan Sanksi Adat Dalam Penistaan Tempat Suci Menurut Hukum Positif}

Indonesia adalah negara hukum adalah istilah yang selalu muncul setiap berbicara masalah hukum karena tidak dapat kita pungkiri tanpa hukum maka kehidupan tidak akan berjalan secara damai. Istilah tersebut dapat dibuktikan misalnya dalam hukum pidana yang menganut beberapa asas yang mana salah satunya adalah asas legalitas yang mengartikan bahwa suatu perbuatan tidak dapat dipidana kecuali berdasarkan kekuatan ketentuan perundangundangan pidana yang telah ada. Asas legalitas yang diadopsi dalam Kitab Undang-Undang Hukum Pidana (KUHP) tersebut berasal dari ajaran Montesqueu yang mengemukakan ajaran trias politika (Hadikusuma, 1984).

Hukum yang mengatur masyarakat Indonesia secara menyeluruh adalah hukum nasional yang tentu saja harus ditaati oleh seluruh orang baik yang menetap ataupun yang sedang berada dalam wilayah Indonesia. Selain hukum nasional tersebut dikenal juga adanya hukum islam dan hukum adat. Hukum adat diketahui telah hidup dan berkembang dalam masyarakat Indonesia sejak dahulu dengan berdasarkan pada nilai-nilai yang hidup dalam masyarakat itu sendiri seperti misalnya nilai asli yang memang telah dihormati di lingkungan masyarakat tertentu maupun nilai sinkretis yang merupakan perpaduan antara nilainilai yang datang dari luar dan hanya berlaku bagi masyarakat di lingkungan tersebut saja. Fungsi dari keberadaan hukum adat pada dasarnya adalah untuk membentuk suatu keseimbangan antara masyarakat itu baik secara individu maupun antar kelompok yang tergabung dalam masyarakat adat.

Masyarakat adat telah ada sejak dahulu bahkan sebelum Indonesia menggunakan system hukum nasional karena bangsa Indonesia terdiri dari berbagai suku. Suku yang berada di Indonesia memiliki adat istiadat sendiri yang mana di dalamnya terdapat budaya, tradisi, system pemerintahan adat dan pastinya memiliki aturan adat juga. Pengakuan terhadap masyarakat adat dapat dilihat dalam Pasal 18B Undang-Undang Negara Republik Indonesia Tahun 1945, dimana dikatakan bahwa Negara mengakui dan menghormati kesatuan-kesatuan Masyarakat Hukum Adat beserta hak-hak tradisionalnya sepanjang masih hidup dan sesuai dengan perkembangan masyarakat dan prinsip negara kesatuan republic Indonesia yang diatur dalam undang-undang. Selain itu pasal 28I ayat (3) juga menyebutkan bahwa identitas budaya dan masyarakat tradisional dihormati selaras dengan perkembangan zaman dan peradaban.

Masyarakat adat di Bali yang sangat kental dengan adat istiadatnya sangat melindungi tempat suci ataupun tempat sacral yang diyakini sebagai jembatan untuk mencapai keseimbangan antara makhluk hidup dengan Tuhan maha pencipta. Oleh sebab itu masyarakat adat di Bali sangat mengutuk keras apabila ada yang merusak tempat suci tersebut karena dengan begitu akan dianggap menodai diri mereka sendiri maupun lingkungan sekitar terlebih lagi dengan perbuatan-perbuatan yang dianggap sebagai suatu penistaan atau penodaan.

Penistaan apabila kita lihat secara umum dapat diartikan sebagai ucapan atau perkataan yang disengaja dan tidak disengaja atau tindakan komunikasi yang dapat dilakukan oleh seseorang mapun kelompok dalam bentuk hasutan atau hinaan kepada orang lain ataupun kelompok lain dalam banyak aspek misalnya etnis, gender, ras, kondisi fisik,kewarganegaraan, agama dan lain sebagainya. Kitab undang-undang hukum pidana (KUHP) merumuskan bahwa yang dimaksud dengan "menista" adalah menyerang kehormatan dan nama baik seseorang, yang mana dapat dibagi menjadi 6 macam yaitu :

Menista secara lisan

Menista dengan surat/tertulis

Memfitnah

Penghinaan ringan

Mengadu secara memfitnah

Tuduhan secara memfitnah

Dalam KUHP tersebut dapat dilihat yang dimaksud penistaan itu adalah lebih kepada dilakukan oleh seseorang atau kelompok kepada orang atau kelompok lain. Seiring berkembangnya jaman penistaan bukan hanya dilakukan terhadap orang atau kelompok lain tetapi perbuatan orang atau kelompok lain yang dilakukan terhadap atau di tempat suci dapat pula dikatan penistaan terhadap tempat suci, terlebih lagi apabila ini dilakukan di Bali yang sangat menghormati kesakralan tempat suci.

Penistaan tempat suci apabila kita telaah dapat 
dikategorikan sebagai suatu tindak pidana karena perbuatan tersebut dapat menganggu ketertiban umum dan dapat menimbulkan perasaan penghinaan terhadap suatu orang atau kelompok. Perlu digaris bawahi disini penistaan yang dimaksud bukan hanya perbuatan seperti mengeluarkan kata-kata yang bersifat menghina atau mengejek tetapi melakukan suatu perbuatan yang seharusnya tidak dilakukan di tempat suci juga dapat dikategorikan sebagai penistaan.

Apabila kita melihat dalam KUHP yang merupakan produk hukum nasional yang mengikat seluruh individu yang berada dalam wilayah Indonesia maka kita tidak akan menemukan mengenai mengenai penistaan atau penodaan terhadap tempat suci. Di dalam KUHP yang dapat kita temukan adalah tindak pidana yang ditujukan terhadap agama yang dapat ditemukan pada pasal 156, pasal 156a, pasal 157 yang dapat dijabarkan sebagai berikut :

Pasal 156:

Barang siapa di muka umum menyatakan perasaan permusuhan, kebencian atau penghinaan terhadap suatu atau beberapa golongan rakyat Indonesia, diancam dengan ancaman pidana penjara paling lama empat tahun atau pidana denda paling banyak empat ribu lima ratus rupiah.

Pasal 156a :

Dipidana dengan pidana penjara selamalamanya lima tahun barang siapa dengan sengaja di muka umum mengeluarkan perasaan atau melakukan perbuatan :

Yang pada pokoknya bersifat permusuhan, penyalahgunaan atau penodaan terhadap suatu agama yang dianut di Indonesia;

Dengan maksud agar supaya orang tidak menganut agama apapun juga, yang bersendikan Ketuhanan Yang Maha Esa.

\section{Pasal 157 (1) :}

Barang siapa menyiarkan, mempertunjukan, atau menempelkan tulisan atau lukisan di muka umum, yang isinya mengandung pernyataan perasaan permusuhan, kebencian atau penghinaan di antara atau terhadap golongan-golongan rakyat Indonesia, dengan maksud supaya isinya diketahui atau lebih diketahui oleh umum, diancam dengan pidana penjara paling lama dua tahun enam bulan atau pidana denda paling banyak empat ribu lima ratus rupiah.
Jika yang bersalah melakukan kejahatan tersebut pada waktu menjalankan pencariannya dan pada saat itu belum lewat lima tahun sejak pemidanaannya menjadi tetap karena kejahatan semacam itu juga yang bersangkutan dapat dilarang menjalankan pencarian tersebut.

Menurut ahli hukum kriminalisasi tindak pidana agama yang diatur dalam KUHP tersebut jika ditinjau dari teori hukum pidana mencakup tiga teori perlindungan yaitu: (Arief, 2010)

Teori perlindungan agama (ReligionsschutzTheorie) Menurut teori ini, agama dilihat sebagai kepentingan hukum atau objek yang akan dilindungi oleh negara, melalui peraturan perundang-undangan yang dibuatnya

Teori perlindungan perasaan keagamaan (Gefuhlsschutz-Theorie) Menurut teori ini, kepentingan hukum yang akan dilindungi adalah rasa/perasaan keagamaan dari orang-orang yang beragama

Teori perlindungan perdamaian/ketentraman umat beragama (Friedensschutz-Theorie). Objek atau kepentingan hukum yang dilindungi menurut teori ini adalah kedamaian/ketentraman beragama diantara pemeluk agama atau dengan pengertian lain lebih tertuju pada ketertiban umum yang dilindungi.

Apabila menilik teori yang dikemukakan tersebut dikaitkan dengan penistaan tempat suci maka perbuatan menistakan atau menodai tempat suci juga memiliki "hak" yang sama untuk dilindungi seperti halnya dengan penistaan agama. Dikatakan demikian karena apabila terjadi tindakan penistaan terhadap tempat suci maka akan melukai perasaan keagamaan dari orang beragama yang tempat sucinya dinodai dan dapat hal ini tentu saja bisa merusak kedamaian atau ketentraman masyarakat terutama masyarakat adat yang sudah susah payah menjaga kesucian tempat suci mereka. Hal yang demikian memperlihatkan adanya kekosongan peraturan terutama dalam hukum nasional mengenai penistaan tempat suci.

Penistaan tempat suci di Bali dapat dikategorikan sebagai pelanggaran hukum adat dan dapat menyebabkan konflik adat. Belakangan ini di Bali sering terjadi beberapa tindakan yang tergolong sebagai penistaan tempat suci yang berada di wilayah Daya Tarik Wisata (DTW) seperti misalnya seorang wisatawan asing yang menduduki pelinggih/padmasana yang merupakan benda suci bagi umat Hindu di Pura 
Besakih yang merupakan tempat ibadah Umat Hindu dan ada pula tindakan wisatawan yang dianggap sebagai penistaan tempat suci yaitu dua orang turis yang dengan sengaja membersihkan bokongnya di sumber air suci di Petirtaan Monkey Forest.

Seperti yang dijelaskan diatas bahwa Indonesia adalah negara Hukum dan berdasarkan dengan teori negara hukum yang meyatakan bahwa negara haruslah berdasarkan UndangUndang atau peraturan lain yang mengatur maka untuk menyelesaikan permasalahan penistaan tempat suci yang dalam hukum nasional belum diatur secara jelas digunakan alternatif lainnya yaitu menerapkan sanksi adat. Hal ini dilakukan agar tetap menimbulkan efek jera dan sekaligus mensosialisasikan kepada masyarakat luas bahwa ada tindakan-tindakan yang dilarang dilakukan ditempat suci. Tetapi walaupun dapat menerapkan sanksi adat keputusan mengenai hal ini juga harus melalui persetujuan masyarakat adat yang berada di wilayah terjadinya penistaan tempat suci.

Sanksi adat dalam kesatuan masyarakat adat Bali terdiri dari beberapa jenis yaitu: (Windia \& Sudantra I, K, 2006)

Arta danda : golongan sanksi adat dalam bentuk materi yaitu dengan cara membayar uang atau penggantian harta benda (benda-benda materiil).

Sangaskara danda : Sanksi Berupa pelaksanaan upacara tertentu sesuai dengan ajaran Agama Hindu, misalnya upacara pembersihan yang memiliki tujuan untuk mengembalikan keseimbangan magis.

Jiwa danda : sanksi berupa penderitaan jasmani dan rohani/jiwa

Penistaan tempat suci khususnya yang terjadi di Bali yang pada kenyataan belum diatur dalam hukum nasional dapat diselesaikan sementara dengan menggunakan sanksi adat tersebut. Pelaku dapat saja dikenakan sanksi berbentuk materi yaitu dengan membayarkan seluruh biaya yang digunakan untuk mengembalikan nilai kesucian dari tempat suci tersebut atau bisa juga dengan hanya ikut hadir untuk mendoakan kembali tempat suci yang telah dinodai tersebut bahkan tidak menutup kemungkinan pilihan berupa penderitaan jasmani dan rohani yang dipilih untuk menimbulkan efek jera. Hal ini bergantung kepada masyarakat adat yang tempat sucinya dinodai karena perbuatan seseorang.
Penyelesaian Kasus Penistaan Tempat Suci Di Desa Padang Tegal, Kecamatan Ubud, Kabupaten Gianyar

Kasus yang diangkat pada penelitian ini adalah kasus penistaan tempat suci pada kawasan Daya Tarik Wisata (DTW) Monkey Forest yang dilakukan oleh Sabina Dolezalova dan Jdenek Slova warga negara Republik Ceko. Kasus ini bermula ketika kedua WNI ini mengunggah foto sedang mencuci bokongnya di pancoran Pura Beji Padangtegal pada media sosial. Kejadian ini baru diketahui oleh prajuru desa tiga hari kemudian dan langsung diadakan mediasi antara pelaku dengan kantor migrasi Denpasar, Polsek Ubund, serta semua prajuru desa setempat.

Kasus ini bermula ketika Sabina Dolezalova dan Jdenek Slova berkunjung ke objek wisata Monkey Forest dan lebih lanjut masuk ke Pura Beji Padangtegal yang masih terdapat dalam satu kawasan dengan monkey forest. Kedua wisatawan ini melihat ada pancoran di pura beji dan berkeinginan untuk mencuci bagian tubuhnya. Adapun pada pura beji ini sudah terdapat larangan dilarang mencuci kaki, namun wisatawan ini menganggap larangan tersebut hanya untuk bagian kaki saja dan berlanjut mencuci bagian bokongnya. Kejadian tersebut diabadikan oleh pelaku dan diupload pada media sosial mereka. Tiga hari setelah kejadian tersebut, akhirnya prajuru desa mengetahui kejadian tersebut dan langsung berusaha mencari pelaku tersebut dengan bantuan dari pihak imigrasi.

Melalui bantuan pihak Imigrasi dan Polsek Ubud, akhirnya prajuru desa berhasil bertemu dengan para pelaku dan melakukan mediasi. Adapun hasil dari mediasi tersebut adalah pelaku dilarang untuk kembali ke negara asalnya sampai upacara guru piduka dilaksanakan dan para pelaku ini harus hadir pada upacara tersebut. Biaya upakara ini tidak dibebankan kepada para pelaku dan murni ditalangi oleh dana Desa Padang Tegal. Setelah kejadian tersebut, jalan masuk ke petirtan Pura Beji telah ditutup untuk umum dan hanya diperkenankan untuk warga desa Padang Tegal yang memang memilik kepentingan ke Pura Beji tersebut.

Pada kasus di desa Padang Tegal ini, tidak ada sanksi pidana yang diberikan kepada para tersangka. Tersangka hanya dikenakan sanksi adat yaitu tidak diperkenankan untuk meninggalkan Pulau Bali serta menghadiri upakara guru piduka yang diselenggarakan langsung oleh prajuru desa Padang Tegal. Penyelesaiannya pun diselesaikan dengan cara 
mediasi antara prajuru desa adat Padang Tegal, Tersangka, Pihak dari Imigrasi Denpasar, dan Polsek Ubud.

Mediasi merupakan salah satu cara penyelesaian sengketa melalui proses perundingan untuk memperoleh kesepakatan para pihak dengan dibantu oleh mediator (Ketua Mahkamah Agung RI, PERMA RI No. 1 Tahun 2008). Mediasi berasal dari Bahasa Inggris yang berarti menyelesaikan sengketa dengan menengahi. Mediasi merupakan proses negosi pemecah masalah, dimana pihak luar yang tidak memihak (impartial) bekerjasama dengan pihak yang bersengketa untuk mencari kesepakatan bersama. Mediator tidak berwenang untuk memutus sengketa, tetapi hanya membantu para pihak untuk menyelesaikan persoalan-persoalan yang dikuasakan kepadanya (Umam, 2010).

Proses penyelesaian sengketa melalui mediasi sangat efektif untuk menyelesaikan sengketasengketa yang melibatkan para pihak atau melibatkan masyarakat, seperti sengketa mengenai perusakan lingkungan, pembebasan tanah, perburuhan, perlindungan konsumen, dan lain-lain. Dengan menggunakan jasa mediator orang tidak perlu beramai-ramai ke Pengadilan atau sendiri-sendiri dalam menyelesaikan sengketa yang bersengketa. Dengan menggunakan metode mediasi para pihak yang bersengketa akan memperoleh keuntungan yang lebih dibandingkan dengan menggunakan jalur litigasi. Dengan mediasi ini para pihak lebih sedikit menderita kerugian, hal ini akan sangat terasa oleh pihak yang dikalahkan jika para pihak menggunakan proses litigasi. Dengan menggunakan mediasi yang bersifat tidak formal, sukarela, kooperatif, dan berdasarkan kepentingan, seorang mediator membantu para pihak untuk merangkai suatu kesepakatan, memenuhi kebutuhannya, dan memenuhi standar kejujuran mereka sendiri.

Dalam proses mediasi kasus penistaan tempat suci di Desa Adat Padang Tegal ini dihasilkanlah putusan bahwa perlu diselenggarakannya upacara guru piduka untuk mengembalikan kesucian dari Pura Beji tersebut dan para pelaku harus ikut menghadiri upacara tersebut sebagai bentuk tanggung jawab dari perbuatannya. Adapun Upacara guru piduka adalah nama upakara, sesajen, atau banten yang digunakan dalam upacara agama Hindu. Upakara ini dipersembahkan kepada Ida Sang Hyang Widhi Wasa atau leluhur sebagai sarana untuk permohonan maaf dan memohon waranugrahaNya. Guru piduka berasa dari kara Guru dan Piduka. Guru menurut kamus sansekerta Indonesia berarti berat, sesar, luas, hebat, penting dan nama lain dari Dewa Siwa. Guru juga berarti Sesajen berupa Tumpeng Peggum yaitu tumpeng di isi telur itik direbus pada ujungnya dan di persembahkan kepada Dewa Siwa (Kamus Kawi Indonesia). Kata Piduka berasal dari kata duka berarti marah, kesusahan, kesukaran. Dan dapat juga berasal dari kata paduka yang artinya julukan Bhatara yang mulia, semoga Tuhan yang mulia memberi anugrah yang utama. Adapun tanda tanda perlu diadakannya upakara khusus banten Guru Piduka adalah adanya suatu kejadian aneh seperti kejadian yang tidak pernah terjadi atau di alami, baik disebabkan oleh alam, manusia, dan hewan, sehingga menimbulkan firasat buruk antara buana alit dan buana agung, lahir dan bathin. Kejadian-kejadian tersebut antara lain:

Kejadian akibat adanya bencana yang menimpa manusia misalnya:

Sakit berkepanjangan tak sembuh-sembuh;

Banyak orang mati dalam waktu singkat;

Sering terjadi mati salah pati, ulah pati;

Terjadinya hubungan "salah timpal" yaitu antara manusia dengan binatang, binatang dengan lain jenis binatang;

Terjadinya hubungan gamia gemana yaitu hubungan orang tua dengan anak, anak dengan saudara kandung.

Kematian salah satu keluarga bertepatan dengan hari piodalan di pemerajan/ pura setempat berdomisili

Keributan terus menerus dalam keluarga, kurang harmonisnya hubungan dengan leluhur.

Terbakarnya tempat suci baik oleh api maupun halilintar serta diperusak oleh angina puyuh.

Tempat suci atau kahyangan tertimpa "Cemei" (kotoran)

Pada bangunan suci / kahyangan yang kena kotoran seperti ada mayat manusia, darah manusia datang bulan, orang bersetubuh di kahyangan, tulang bangkai manusia di kahyangan, suara tangis pelan, disambar petir, mati bunuh diri, dimasuki binatang piaraan berkaki empat, perlu diadakan / dipersembahkan guru piduka. 
Upacara ini memang harus dilakukan oleh desa yang bangunan sucinya sudah terkena "kotor". Bahkan dalam kasus ini para tersangka tidak dibebankan biaya upacara tersebut, hanya harus menghadiri.

Desa adat Padang Tegal dalam kasus ini sudah tepat menggunakan proses mediasi karena merupakan jalan satu-satunya penyelesian kasus ini. Hal ini terjadi karena dalam peraturan perundang-undangan di Indonesia belum ada yang mengatur mengenai penistaan tempat suci seperti kasus ini. Jadi peran adat dalam melakukan mediasi dengan tersangka sangatlah penting untuk menyelesaikan kasus tersebut. Namun menurut peneliti, adapun sanksi adat yang diberikan kepada pelaku melalui jalur mediasi ini kurang memberikan efek jera terhadap pelaku. Tetap harus ada sanksi pidana maupun sanksi administrative yang bersifat mengikat kepada para pelaku penistaan tempat suci tidak hanya di Bali, tetapi juga di Indonesia. Ini diperuntukan agar tidak ada lagi kasus-kasus penistaan tempat suci yang sudah sangat sering terjadi dan tidak hanya dilakukan oleh Warga Negara Asing (WNA) tetapi juga Warga Negara Indonesia (WNI).

Sejatinya, terkait kasus penistaan tempat suci yang sudah sering terjadi ini maka menurut peneliti sangatlah urgen untuk segera dibentuknya suatu peraturan perundang-undangan terkait penistaan tempat suci ini. Di Bali, anggota DPRD sudah melakukan beberapa upaya untuk membentuk suatu aturan hukum terkait permasalahan ini yaitu dengan berupaya membentuk Ranperda Standar Penyelenggaraan Kepariwisataan namun hingga kini ranperda tersebut belum terealisasikan.

Penjatuhan sanksi pidana pada tindak pidana penistaan tempat suci ini menurut peneliti juga didukung berdasarkan teori pemidanaan. Adapun teori pemidanaan yang kami gunakan adalah Teori gabungan (integratif) mendasarkan pidana pada asas pembalasan dan asas tertib pertahanan tata tertib masyarakat, dengan kata lain dua alasan itu menjadi dasar dari penjatuhan pidana. Pada dasarnya teori gabungan adalah gabungan teori absolut dan teori relatif. Gabungan kedua teori itu mengajarkan bahwa penjatuhan hukuman adalah untuk mempertahankan tata tertib hukum dalam masyarakat dan memperbaiki pribadi si penjahat. Dengan pemberian sanksi pidana pada tindak pidana penistaan tempat suci ini diharapkan kedepannya berdampak pada penurunan kasus penistaan tempat suci yang menjadi Daya Tarik Wisata (DTW) baik oleh WNA maupun WNI serta lebih memberikan efek jera bagi para pelaku.

\section{IV.SIMPULAN}

Berdasarkan pemaparan di atas maka dapat disimpulkan bahwa Produk hukum nasional di Indonesia belum mengatur mengenai penistaan terhadap tempat suci secara nyata. Di dalam KUHP hanya diatur mengenai penistaan agama tidak disinggung sedikitpun mengenai penistaan tempat suci dan apabila terjadi kasus ini maka akan diselesaikan secara hukum adat dengan memberikan sanksi adat. Sanksi adat dalam kesatuan masyarakat bali terdiri dari Arta danda (sanksi dalam bentuk materi), Sangaskara danda (melaksanakan upacara tertentu sesuai ajaran agama Hindu, Jiwa danda (sanksi berupa penderitaan jasmani dan rohani. Untuk menimbulkan efek jera terhadap pelaku penistaan tempat suci di Bali maka dapat dijatuhkan salah satu ataupun semua sanksi adat tersebut hal ini tergantung dari keputusan masyarakat adat yang berada di wilayah tempat suci tersebut berada.

Pada Desa adat Padang Tegal dalam kasus ini sudah tepat menggunakan proses mediasi karena merupakan jalan satu-satunya penyelesian kasus ini. Hal ini terjadi karena dalam peraturan perundang-undangan di Indonesia belum ada yang mengatur mengenai penistaan tempat suci seperti kasus ini. Jadi peran adat dalam melakukan mediasi dengan tersangka sangatlah penting untuk menyelesaikan kasus tersebut. Namun menurut peneliti, adapun sanksi adat yang diberikan kepada pelaku melalui jalur mediasi ini kurang memberikan efek jera terhadap pelaku. Tetap harus ada sanksi pidana maupun sanksi administrative yang bersifat mengikat kepada para pelaku penistaan tempat suci tidak hanya di Bali, tetapi juga di Indonesia. Ini diperuntukan agar tidak ada lagi kasus-kasus penistaan tempat suci yang sudah sangat sering terjadi dan tidak hanya dilakukan oleh Warga Negara Asing (WNA) tetapi juga Warga Negara Indonesia (WNI).

Melihat kasus yang terjadi di Desa adat Padang Tegal maka penulis ingin memberikan saran yang mungkin saja dapat menjadi bahan pertimbangan agar terciptanya perlindungan hukum yaitu kepada pemerintah untuk segera membentuk peraturan perundang-undangan yang mengkhusus mengenai tindak pidana penistaan tempat suci. Serta dapat memberikan pembinaan 
bagi para guide agar lebih menjaga tempat suci yang menjadi daya tarik wisata. Guide diharapkan mampu menjelaskan tata cara untuk masuk ke tempat suci, makna dari tempat suci dan betapa sakralnya tempat suci tersebut bagi masyarakat adat sehingga kedepannya tidak ada lagi wisatawan yang berusaha untuk melecehkan tempat suci yang juga menjadi tujuan wisata. Selain itu diperhatikan juga untuk masyarakat adat agar bersama-sama melakukan pengawasan tempat-tempat suci yang menjadi Daya Tarik Wisata baik dari upaya penistaan maupun pengrusakan.

\section{DAFTAR PUSTAKA}

Arief, B. N. (2010). Delik Agama dan Penghinaan Tuhan (Blasphemy) Di Indonesia dan Perbandingan Berbagai Negara. Semarang: BP UNDIP.

Covarrubias, M. (2013). Pulau Bali: Temuan yang Menakjubkan. Denpasar: Udayana University Press.

Hadikusuma, H. (1984). Hukum Pidana Adat. Bandung: Alumni.

Netra, A. A. G. O. (1997). Tuntunan Dasar Agama Hindu. Jakarta: Hanuman Sakti.

Rustamaji, M., \& Aulia, G. N. (2020). Telaah Konsepsi Penistaan Agama Terhadap

Penegakan Hukum Kasus Meliana (Studi

Putusan Pengadilan Negeri Medan

Nomor:1612/Pid.B/2018/PN.Mdn). Jurnal

Verstek, 8(2). Retrieved from https:// jurnal.uns.ac.id/verstek/issue/view/3117

Soekanto, S. (2007). Pengantar Penelitian Hukum. Jakarta: Universitas Indonesia.

Umam, K. (2010). Penyelesaian Sengketa diluar Pengadilan. Yogyakarta: Pustaka Yustisia.

Windia, W. P., \& Sudantra I, K, P. (2006). Pengantar Hukum Adat Bali. Denpasar: Lembaga Dokumentasi dan Publikasi Fakultas Hukum Universitas Negeri Udayana. 